\title{
FENOMENA FACEBOOK SEBAGAI SARANA KOMUNIKASI SOSIAL
}

\author{
Hadianto Ego Gantiano ${ }^{1}$
}

\begin{abstract}
Abstrak
Pandangan masyarakat yang menganggap bahwa komunikasi sangat penting pada masa kini, secara tidak langsung telah memancing suatau revolusi besar dalam perkembangan teknologi komunikasi. Hal tersebut terlihat dari banyaknya media yang digunakan dalam proses komunikasi. Situs web Facebook memungkinkan Anda menerima permintaan pertemanan dari teman dekat, teman sekolah, kerabat dan bahkan teman lama Anda. Orang yang tidak Anda kenal sebelumnya juga bisa mengajak berteman melalui Facebook. Atau Anda bisa juga memasukkan foto kemudian menandai orang-orang yang ada di foto tersebut, sehingga orang yang ditandai dapat melihat foto tersebut. Anda juga dapat memasukkan jadwal acara dan mengundang orang lain melalui Facebook. Facebook sebagai situs web jejaring sosial memang bisa bermanfaat untuk semua penggunanya. Jika digunakan dengan tepat, Anda bisa menikmati banyak pertemanan yang positif dan bermanfaat. Namun jangan mengendurkan kewaspadaan Anda, karena dibalik banyak manfaatnya, jika disalahgunakan maka Facebook bisa menjadi bahaya yang menghancurkan keluarga. Selalu gunakan Facebook secara bijaksana.
\end{abstract}

Kata kunci : Facebook, Komunikasi, Sosial

\footnotetext{
${ }^{1}$ Penulis adalah dosen Jurusan Dharma Duta STAHN-TP Palangka Raya
} 


\section{PENDAHULUAN}

P e r k e mbang a n i $1 \mathrm{~m} \mathrm{u}$ pengetahuan dan teknologi (selanjutnya disingkat IPTEK) berkembang pesat. $\mathrm{P}$ erkembangan tersebut meliputi berbagai macam sektor, sebagai salah satu contoh Internet merupakan salah satu dari komponen perkembangan IPTEK yang sangat disukai oleh semua elemen masyarakat tanpa terkecuali. Pengertian internet (interconnection networking) sendiri adalah jaringan komunikasi global yang terbuka dan menghubungkan jutaan bahkan milyaran jaringan komputer dengan berbagai tipe dan jenis, dengan menggunakan tipe komunikasi seperti telepon, satelit dan lain sebagainya.

Internet memberikan kemudahan bagi setiap orang untuk memperoleh/ membagikan informasi dan data. Salah satu manfaat dari internet yakni mempermudah dan mempercepat komunikasi. Perkembangan internet yang semakin menjadi-jadi membuat komunikasi antar individu menjadi sangat mudah dan cepat. Kita juga dapat berkomunikasi dengan orang luar negeri sekalipun dengan biaya yang relatif murah. Dalam kehidupan sosial masyarakat, tentunya tidak lepas dari proses komunikasi. Selain mampu memberikan informasi, dan data, layanan internet dewasa ini dimanfaat sebagai sara berkomunikasi. "Medsos" merupakan istilah keren bagi para pengguna layanan Internet, yang memanfaatkan layanan internet tersebut sebagai sarana untuk berkomunikasi.

Perkembangan globalisasi telah mendorong suatu moderensisasi dalam dunia komunikasi. Pandangan masyarakat yang menganggap bahwa komunikasi sangat penting pada masa kini, secara tidak langsung telah memancing suatau revolusi besar dalam perkembangan teknologi komunikasi. Hal tersebut terlihat dari banyaknya media yang digunakan dalam proses komunikasi. Media tersebut sering dikaitkan dengan teknologi komunikasi yang merupakan peralatan perangkat keras (hardware) maupun perangkat lunak (software) dalam sebuah struktur organisasi yang mengandung nilai-nilai sosial, yang memungkinkan setiap individu mengumpulkan, memproses, dan saling tukar menukar informasi dengan individu-individu lainnya

Sudah banyak jejaring sosial seperti Facebook (selanjutnya disingkat FB), yang digunakan pengguna internet untuk berkenalan dan menemukan teman baru di sana. Tidak sedikit juga dari mereka yang ngobrol/ chatting dengan kerabat mereka menggunakan jejaring sosial ini. FB merupakan salah satu media Sosial dalam dunia internet. Kepopuleran FB tidak diragukan lagi, tercatat hingga tahun 2016 ada 88 Juta pengguna aktif $\mathrm{FB}$ di Indonesia (Sumber:http://tekno.kompas.com/read 
/2016/10/20/17062397/jumlah.penggun a.facebook.di.indonesia.terus.bertamba h).

Tren Facebook yang ada di masyarakat cukup kuat, membuat banyak penggemarnya yang akhirnya membeli smartphone dengan tujuan untuk dapat terus mengakses dan memperbahurui statusnya. Facebook memang menarik, sebagai mini blog, Facebook memungkinkan anggotanya untuk menuliskan status di wall, apa yang dirasakan atau apa yang sedang dialaminya, kemudian anggota lain dapat memberikan komentar yang membuatnya semakin seru

Dalam perkembanganya FB tentu memberikan dampak yang signifikan terhadap pola hidup sosial bermasyarakat. Pengguna FB di Indonesia tumbuh begitu cepat, dan saat ini menempati urutan pertumbuhan tercepat kedua di dunia dari sisi jumlah pengguna. Indonesia hanya kalah dari Amerika Serikat yang juga merupakan pengguna FB terbanyak di dunia.

Selanjutnya, dalam tulisan ini akan dibahas bagaimana fenomena penggunaan FB sebagai sarana komunikasi sosial.

\section{PEMBAHASAN}

\subsection{Fenomena Facebook Sebagai}

\section{Sarana Komunikasi Sosial}

Riwayat perkembangan komunikasi antar manusia adalah sama dengan sejarah kehidupan manusia itu sendiri. Menurut Nordenstreng dan Varis ( 1973) dalam ( Nasution, 1989:15), ada empat titik penentu yang utama dalam sejarah komunikasi manusia, yaitu:

1. Ditemukannya bahasa sebagai alat interaksi tercanggih manusia.

2. Berkembangnya seni tulisan dan berkembangnya kemampuan bicara manusia menggunakan bahasa.

3. Berkembangnya kemampuan reproduksi kata-kata tertulis ( written word) dengan menggunakan alat pencetak, sehingga memungkinkan terwujudnya komunikasi massa yang sebenarnya.

4. Lahirnya komunikasi elektronik, mulai dari telegraf, telepon, radio, televisi hingga satelit

Dalam perkembangannya komunikasi lewat media komputer terjadi peleburan antara komunikasi mediation dan immediate. Mediation mengacu pada proses pertukaran pesan dimana pesan disampaikan melalui perantara media bentuk teknologi dari yang paling sederhana seperti kertas, sampai teknologi canggih seperti komputer internet. I mmediate merupakan proses komunikasi tatap muka secara langsung tanpa adanya media perantara apapun.

Facebook adalah website yang di dirikan oleh Mark Zuckerberg 
seorang mahasiswa Harvard. Situs ini telah di luncurkan sejak 4 Febuari 2004. Meski Facebook telah lahir sejak tahun 2004 namun penggunaan jejaring sosial di internet ini baru meningkat pesat di Indonesia pada tahun 2008 yang meninggalkan situs jejaring yang populer sebelumnya yaitu Friendster.com. Pada awal nya terciptanya facebook, facebook sendiri hanya dikhususkan untuk seorang mahasiswa di universitas Harvard yang berada diluar negeri, dan setelah tahun 2005 facebook mulai ditunjukan untuk kalangan anak sekolahan, dan juga kalangan remaja, dan pada tahun 2006 facebook pun mulai berbaur dan terbuka untuk siapa saja ( seluruh dunia ) dan semua pun bisa menggunakan facebook. Sampai hingga saat ini sudah hampir semua orang di Indonesia memiliki akun Facebook. Hal ini diperkuat akibat dampak dari globalisasi dan kemajuan teknologi. Saat ini jutaan orang online setiap harinya,dan mereka tidak online hanya dengan menggunakan komputer. Saat ini orang sudah dapat mengakses Facebook melalu ponsel mereka, sehingga mereka bisa online di Facebook kapan saja dan dimana saja.

Kini pertumbuhan pengguna dan pengakses Facebook diseluruh dunia sudah melesat sedemikian jauh dan semakin popular dan sebagai konsekuensi pemilihan oleh masyarakat, Facebook menenggelamkan popularitas situs jejaring sosial yang sudah ada sebelumnya dan sedang mengalami fase booming, yaitu Friendster, Live Connector, dan MySpace. Bahkan intensitas pemakaian dan akses oleh masyarakat diseluruh dunia setiap harinya, bisa disejajarkan dengan mesin pencari Google atau Yahoo. Facebook kini berkembang sebagai mesin interface raksasa dengan jutaan pengguna. Tampilannya yang sederhana, fiturnya yang komplit, dan pengoperasian yang user friendly, membuat Facebook semakin membuat orang tertarik untuk mengakses dan menggunakannya. Facebook tanpa disadari telah banyak mempengaruhi dunia sosialita, pendidikan, bisnis, dan bidang lainnya di kehidupan masyarakat yang berasal dari berbagai kalangan dan berbagai latar belakang sosial.

$$
\text { Situs web Facebook }
$$
memungkinkan Anda menerima permintaan pertemanan dari teman dekat, teman sekolah, kerabat dan bahkan teman lama Anda. Orang yang tidak Anda kenal sebelumnya juga bisa mengajak berteman melalui Facebook. Atau Anda bisa juga memasukkan foto kemudian menandai orang-orang yang ada di foto tersebut, sehingga orang yang ditandai dapat melihat foto tersebut. Anda juga dapat memasukkan jadwal acara dan mengundang orang lain melalui Facebook. Fitur lain adalah Anda dapat chating atau mengobrol 
dengan anggota lain yang merupakan teman Anda bila sedang online bersamaan.

Awal kemunculan dan boomingnya Facebook dirasakan sangat membawa perubahan dalam sosial masyarakat. Rekan lama yang mungkin sudah belasan tahun tidak bertemu, bisa dipertemukan lewat Facebook, dan tidak jarang Facebook malah dijadikan ajang untuk mencari jodoh, memasarkan produk secara online, atau membentuk dan menonjolkan eksistensi suatu komunitas tertentu sesuai hobi. Dengan kemudahan yang ditawarkan, Facebook masih tetap eksis walaupun semakin banyak mesin jejaring sosial yang bermunculan seperti Twitter, Flixster, atau Yahoo Koprol.

Aplikasi jejaring sosial seperti facebook menawarkan platform yang efisien bagi setiap kegiatan dengan memperluas jaringan dan hubungan akrab. Situs jejaring sosial seperti facebook bisa membantu setiap orang dalam berinteraksi secara sosial dan akademik yang akhirnya meningkatkan hasil kinerja. Pengaruh Facebook dalam kehidupan sosial sangat besar, di lingkungan sosial facebook dapat menjadi wadah dimana setiap orang dapat mengenal orang baru yang berasal dari berbagai belahan dunia dan daerah, tanpa harus bertemu dan berkomunikasi secara face to face, bisa berkomunikasi dengan kawan lama yang sudah lama tidak berjumpa, mengetahui segala macam informasi yang up to date dari teman - teman yang bergabung dalam lingkungan pertemanan Facebook, dapat membangun relasi bisnis karna mulai banyak individu maupun coorporate yang mengiklankan bisnisnya, pengiriman pesan dari satu orang bisa di terima oleh banyak orang.

Sekarang ini anak-anak dibawah umur pun sudah memiliki akun Facebok sendiri, walaupun sebenarnya Facebook memiliki batas minimal umur untuk membuat akun Facebook. Namun mereka dibuatkan akun Facebook oleh orangtuanya. Bagi para orang tua yang membuatkan akun Facebook untuk anaknya yang masih di bawah umur,mereka harus selalu mengawasi aktifitas anak mereka.

\subsection{D a m p ak P enggun a n Facebook Sebagai Sarana Komunikasi Sosial}

B anyaknya pengguna Facebook di Indonesia menyebabkan berbagai dampak pula khususnya di bidang sosial. Memang permasalahan utamanya tidak berasal dari Facebook secara langsung, namun dalam kasus ini Facebook dapat menjadi suatu media untuk berbagi cerita yang dapat menimbulkan masalah. Dampak penggunaan Facebook tidak hanya negatif, namun ada juga sisi positifnya. Facebook menjadi media 
untuk mengekspresikan kebebasan hingga berdampak negatif.

\subsubsection{Dampak Positif Penggunaan}

Facebook Sebagai Sarana Komunikasi Sosial

a. Menjalin komunikasi

b. Refreshing selesai bekerja di kantor seperti bermain game di facebook.

c. B is nis, karena facebook menyediakan fitur untuk tempat beriklan.

d. Tempat curhat,di facebook dapat menulis perasaanmu saat ini di status atau menuliskannya di note. Temanteman yang tanggap dan peduli akan memberikan komentar, serta mencari jalan keluar dari masalah yang kita hadapi. Bisa juga menggunakan fitur chat untuk melakukannya.

e. Praktis sebab facebook memiliki banyak fasilitas dan komplit seperti chatting.Tempat mencari jodoh dengan berpedoman pada agama dan norma yang berlaku.

f. Tempat berkampanye politik yang murah meriah dan menjanjikan hasil.

g. Memperbanyak sahabat tempat saling berbagi pengalaman, solusi atau sharing, tempat menemukan kembali teman yang lama tak bertemu.

h. Tempat berkumpul dan berdiskusi dengan pengguna yang sama profesi melalui sebuah komuntas professional. i. Untuk mengetahui potensi diri, dalam facebook banyak terdapat kuis yang bermanfaat untuk mengetahui lebih banyak tentang diri sendiri dan juga game yang menarik untuk dimainkan.

j. Sebagai media penyimpanan file sebab di Facebook memiliki fitur untuk upload dan bisa dijadikan media penyimpanan foto. Space yang disediakan sudah sangat mencukupi. (sumber:http://www.pjtv.co.id/raga m/read/gayahidup/193/10-dampaknegatif-facebook-bagi-pelajar-danremaja.html)

Berdasarkan pendapat dari sumber tersebut mengisyaratkan bahwa facebook memiliki dampak yang baik, Perkembangan teknologi komunikasi mampu dimanfaatkan untuk melakukan hal-hal yang positif. Sehingga terwujudnya masyarakat sosial yang harmonis dan komunikatif.

\subsubsection{Dampak Negatif Penggunaan} Facebook Sebagai Sarana Komunikasi Sosial

Namun perlu kita sadari bahwa facebook dapat menimbukan dampak negatif, seperti kejahatan di dunia maya atau cyber crime yang dilakukan oleh oknum-oknum y a n t idak bertanggungjawab dengan mengirimkan konten yang bersifat negatif, seperti kata-kata kasar, bahkan gambar atau video porno. Hal ini dapat berdampak 
kurang baik terhadap kohesivitas masyarakat. Diawali dengan timbulnya kontravensi atau keadaan tidak puas, benci dan kecewa di antara pengguna facebook dan kelompoknya. Lebih l a n j u t, S ing g i h (2011:83) mengemukakan konflik antara individu atau kelompok yang berkepanjangan dan menyebabkan disintegrasi atau perpecahan yang berakibat buruk bagi kohesivitas masyarakat.

Update status, upload foto, mengobrol atau melihat dinding orang lain bisa sangat mengasyikan dan membuat lupa waktu. Hal itulah yang sering dirasakan para anggota Facebook. Maka, agar tidak lupa waktu perlu disiplin yang baik. Untuk anak Anda, tetapkan peraturan berapa lama mereka boleh mengakses Internet sehingga tidak kehabisan waktu untuk istirahat, belajar atau melakukan kegiatan lainnya.

Bagi pasangan yang telah menikah, menggunakan Facebook dapat menyebabkan keretakan dalam hubungan mereka. Bila Anda melihat kata-kata romantis yang dikirimkan oleh seorang lawan jenis dari suami atau istri Anda mungkin dapat menyebabkan pertengkaran. Atau dengan Facebook, komunikasi dengan lawan jenis bisa sangat akrab, membuat Anda sering menceritakan masalah Anda kepadanya dapat membuat pada akhirnya Anda tertarik pada orang tersebut, bukan pada pasangan sendiri.
Mencantumkan biodata lengkap, bahkan sampai nomor telepon atau alamat rumah dapat memancing orang yang tidak bertanggung jawab. Hal ini karena bila tidak diatur secara khusus, semua orang dapat membaca informasi ini. Dan jika informasi ini digunakan oleh orang yang berniat jahat, maka hal itu dengan mudah dapat dilakukan. Lindungi privasi Anda meski merasa yakin bahwa situs tersebut telah benarbenar aman. Bagikan informasi Anda hanya kepada orang yang benar-benar Anda kenal. Abaikan ajakan pertemanan jika Anda curiga terhadap keanggotaan orang tersebut di Facebook. Bahkan jika Anda sudah mendapat ancaman atau tindakan kurang menyenangkan dari orang lain di Facebook, Anda bisa melaporkan orang tersebut kepada pengelola Facebook.

Banyak orang berlomba ingin memiliki teman sebanyak mungkin di Facebook. Selalu periksa siapa yang Anda ajak berteman dan siapa yang mengajak Anda menjadi temannya. Karena bisa jadi Anda hanya berteman dengan orang yang bermaksud jahat atau mengirim spam di dinding Anda.

Beragam aplikasi menarik juga tersedia di Facebook. Namun beberapa dari aplikasi ini bisa mengandung virus atau aplikasi yang berbahaya. Jika ada undangan untuk menggunakan aplikasi tertentu, dan Anda tidak yakin maka abaikan saja undangan tersebut. Anda 
bisa bertanya kepada orang lain atau teman Anda yang sudah menggunakan aplikasi tersebut untuk meminta rekomendasinya.

Selanjutnya, berikut merupakan dampak negatif dari penggunaan facebook:

a. Tidak peduli dengan sekitarnya

Orang yang sudah kecanduan facebook terlalu asyik dengan dunianya sendiri (dunia yang diciptakannya) sehingga tidak peduli dengan orang lain dan lingkungan di sekitarnya. Seseorang yang telah kecanduan facebook sering mengalami hal ini. Tidak peduli dengan lingkungan sekitar, dunianya berubah menjadi dunia facebook.

b. Kurangnya sosialisasi dengan lingkungan

Ini dampak dari terlalu sering dan terlalu lama bermain facebook. Ini cukup mengkhawatirkan bagi perkembangan kehidupan sosial si anak. Mereka yang seharusnya belajar sosialisai dengan lingkungan justru lebih banyak menghabiskan waktu lebih banyak di dunia maya bersama teman teman facebooknya yang rata rata membahas sesuatu yang nggak penting. Akibatnya kemampuan verbal si anak menurun. Tentu yang dimaksud autis di sini bukan dalam arti yang sebenarnya. c. Menghamburkan uang

Akses internet untuk membuka facebook jelas berpengaruh terhadap kondisi keuangan (terlebih kalau akses dari warnet). Dan biaya internet di Indonesia yang cenderung masih mahal bila dibanding negara negara lain (mereka sudah banyak yg gratis). Ini sudah bisa dikategorikan sebagai pemborosan, karena tidak produktif. Lain soal jika mereka menggunakannya untuk kepentingan bisnis.

d. Mengganggu kesehatan

Terlalu banyak nongkrong di depan monitor tanpa melakukan kegiatan apa pun, tidak pernah olah raga sangat beresiko bagi kesehatan. Penyakit akan mudah datang. Telat makan dan tidur tidak teratur. Obesitas (kegemukan), penyakit lambung (pencernaan), dan penyakit mata adalah gangguan kesehatan yang paling mungkin terjadi.

e. Kurangnya perhatian untuk keluarga

Keluarga di rumah adalah nomor satu. Slogan tersebut tidak lagi berlaku bagi para facebookers. Buat mereka temen temen di facebook adalah nomor satu. Tidak jarang perhatian mereka terhadap keluarga menjadi berkurang. 
f. Tersebarnya data pribadi

B e berapa facebookers memberikan data data mengenai dirinya dengan sangat detail. Biasanya ini untuk orang yang baru kenal internet hanya sebatas facebook saja. Mereka tidak tahu resikonya menyebarkan data pribadi di internet. Ingat data data di internet mudah sekali bocor, apalagi facebook yang gampang sekali di hack!

g. Mudah menemukan sesuatu berbau pornografi

Mudah sekali bagi para facebookers menemukan sesuatu yang berbau pornografi. Karena hal itu yang paling banyak dicari di internet dan juga paling mudah ditemukan. nah, inilah fakta tidak dewasanya pengguna internet Indonesia. Hanya menggunakan internet untuk mencari konten "berlendir". Di facebook akan sangat mudah menemukan grup sex, grup tante kesepian, grup cewek bispak dsb.

h. Rawan terjadinya perselisihan

Tidak adanya kontrol dari pengelola facebook terhadap para anggotnya dan ketidak dewasaan pengguna facebook itu sendiri membuat pergesekan antar facebookers sering sekali terjadi.

i. Rawan terjadi penipuan

Seperti media media lainnya, facebook juga rawan terhadap penipuan. Apalagi bagi anak anak yang kurang mengerti tentang seluk beluk dunia internet. Bagi si penipu sendiri, kondisi dunia maya yang serba anonim jelas sangat menguntungkan.

(Sumber:http://kumpulan.info/tech/inte rnet / 265 - man fa a t - b a ha y a facebook.html)

\section{PENUTUP}

Masyarakat merupakan orangorang yang berinteraksi dalam sebuah wilayah tertentudan memiliki budaya bersama (John J Macionis, 1997). Selanjutnya, menurut An-Nabhani bahwa masyarakat adalah sekelompok individu seperti manusia yang memiliki pemikiran, perasaan, serta sistem/aturan yang sama dan terjadi interaksi antara sesame karena kesamaan tersebut untuk kebaikan masyarakat itu sendiri. Kedua pendapat tersebut mengisyaratkan bahwa proses komunikasi dalam kehidupan sosial masyrakat sangat berpengaruh dan menentukan kelangsungan kesejahteraan warga masyarakat.

Seiring dengan perkembangan teknologi, hendaknya proses komunikasi semakin dipermudah. Dalam hal ini Facebook yang merupakan salah satu produk dari kemajuan teknologi komunikasi. Melalui layanan facebook, batasan 
ruang dan waktu tidak menjadi hambatan dalam melaksanakan proses komunikasi.

Facebook sebagai situs web jejaring sosial memang bisa bermanfaat untuk semua penggunanya. Jika digunakan dengan tepat, Anda bisa menikmati banyak pertemanan yang positif dan bermanfaat. Namun jangan mengendurkan kewaspadaan kita, karena dibalik banyak manfaatnya, jika disalahgunakan maka Facebook bisa menjadi bahaya yang menghancurkan keluarga. Selalu gunakan Facebook secara bijaksana.

\section{DAFTAR PUSTAKA}

John, Macianis. 998. Sociologi. An exploration of the major methods, theories and findings of the field of sociology. This edition includes new research and statistical data and aims to put greater emphasis on applying, Singaporer

Nasution, Z. 1989. Teknologi Komunikasi dalam Perspektif: Latar Belakang dan Perkembangannya. Jakarta: Lembaga Penerbit Fakultas Ekonomi Universitas Indonesia.

Singgih, E. Evita, et al. Mata Kuliah Pengembangan Kepribadian Terintegrasi A. (Jakarta: Lembaga Penerbit FEUI, 2011)

http://tekno.kompas.com/read/2016/10/20/ 17062397/jumlah.pengguna.facebook.di.in donesia.terus.bertambah

http://www.pjtv.co.id/ragam/read/gayahidu p/193/10-dampak-negatif-facebook-bagi- pelajar-dan-remaja.html http://kumpulan.info/tech/internet/265manfaat-bahaya-facebook.html 
Jurnal Dharma Duta 2017 VOL XV, Januari - Juni 2017 